\title{
PERANAN PEMIMPIN INFORMAL PADA MASYARAKAT GURADOG
}

\author{
Oleh Ani Rostiyati \\ Balai Pelestarian Sejarah dan Nilai Tradisional Bandung \\ Jln. Cinambo No. 136 Ujungberung Bandung \\ Email: ani.rostiyati@yahoo.com
}

\begin{abstract}
Abstrak
Kebergantungan masyarakat pada pemimpin informal yang berperan sebagai pemimpin adat, sangat tinggi. Hal itu disebabkan warga masyarakat meyakini, bahwa pemimpin adat mempunyai kemampuan dan kelebihan tertentu. Masyarakat percaya bahwa kehadiran pemimpin adat dapat memberi ketenangan dan harmoni. Ia dapat merepresentasikan masyarakat untuk berhubungan dengan leluhur. Pemimpin adat merupakan mediator antara masyarakat dengan leluhurnya.

Dengan demikian, pemimpin informal/pemimpin adat mempunyai kedudukan dan peran yang penting. Ia bukan sebagai pemimpin adat yang berperan sebagai pemimpin masyarakat dalam hukum adat dan melindungi tradisi leluhur, tetapi juga sebagai figur yang berperan sebagai mediator pemerintah di bidang sosial dan adat. Pemimpin informal dengan peran demikian itu antara lain terdapat pada masyarakat Guradog, Kabupaten Lebak Propinsi Banten.
\end{abstract}

Kata Kunci: pemimpin informal, adat-istiadat.

\begin{abstract}
People's dependency at informal leader who personating leader of custom, is very high. It is caused by society citizen believe, that leader of custom have certain excess and ability. Society believe that attendance of leader of custom can give harmony and calmness. He can give presentation society to deal with ancestor. Leader of custom represent mediator between society with its ancestor.

Thereby, informal leader / leader of custom have an important status and role. He is not only as leader of custom who personate leader of society in customary law and protect ancestor tradition but also as figure which personate government mediator in social area and custom. Informal leader with role that way for example there are at society of Guradog, Regency of Lebak Province of Banten
\end{abstract}

Keywords: informal leader, custom.

\section{A. Pendahuluan}

Proses pembangunan yang

dilaksanakan di daerah tidak selamanya berjalan sesuai dengan yang diharapkan. Dalam proses pembangunan, pemerintah dihadapkan pada kenyataan kehidupan masyarakat pedesaan yang umumnya masih lekat memegang adat istiadat, sehingga progam pembangunan tidak dapat dilakasanakan sesuai tujuan yang ditetapkan. 
Seringkali terjadi, suatu progam pembangunan yang dilaksanakan di suatu wilayah tidak memperhitungkan faktor sosial dan kebudayaan masyarakatnya, padahal dukungan dan partisipasi masyarakat setempat merupakan suatu keharusan. Pentingnya dukungan dan partisipasi warga masyarakat bukan hanya berkaitan dengan kepentingan program pembangunan tersebut, tetapi berkaitan dengan tujuan pembangunan, yaitu meningkatkan taraf kesejahteraan masyarakat. Tujuan pembangunan tersebut baru akan berhasil bila didasarkan pada kondisi, aspirasi dan kebutuhan masyarakat yang bersangkutan. Bentuk nyata dari dukungan dan partisipasi masyarakat di antaranya dengan memperhatikan keberadaan pemimpin informal tradisional pada masyarakat tersebut. Peranan seorang pemimpin informal tradisional dinilai penting karena dapat berperan ganda, selain sebagai pemimpin masyarakatnya, juga sebagai perantara atau culture agent antara masyarakat yang dipimpinnya dengan pemerintah. Pemimpin informal tradisional di pedesaan, khususnya pemimpin adat, selalu menjadi tokoh panutan yang berperan dalam mengatur dan mempertahankan nilai-nilai adat yang dianut masyarakat, serta sebagai mediator pemerintah untuk menyampaikan progam pembangunan.

Pemimpin informal tradisional di pedesaan memiliki peranan yang cukup besar dalam kehidupan masyarakat, baik sebagai pimpinan adat maupun sebagai media pemerintah. Demikian pula, di Desa Guradog yang merupakan salah satu desa di Kabupaten Lebak Propinsi Banten memiliki pemimpin adat yang disebut olot (ketua adat). Olot (sesepuh adat) sebagai pimpinan adat di Desa Guradog memiliki peranan penting dan menjadi panutan masyarakatnya.
Dalam kehidupan sehari-hari, masyarakat Desa Guradog berpegang teguh pada penuturan olot (sesepuh adat), yang dianggap sebagai pimpinan tertinggi. Beberapa hal yang menurut sesepuh adat dianggap tabu maka harus ditaati oleh masyarakat. Sebagai pemimpin tertinggi mempunyai peranan penting dalam kehidupan sosial masyarakat Guradog. Sesepuh adat juga berperan sebagai media pemerintah untuk menyampaikan progam pembangunan. Dalam kehidupan sosial masyarakat Guradog, sesepuh adat berperan sebagai sesepuh dan pemimpin adat dalam mempertahankan nilai-nilai yang dianut oleh masyarakatnya. Dalam aspek pemerintahan juga ikut membantu perangkat desa dalam menyampaikan progam pembangunan.

Mengingat pentingnya peranan sesepuh adat sebagai pemimpin informal di Desa Guradog, maka perlu adanya penelitian mengenai sejauh mana peranannya dalam kehidupan masyarakat, yang meliputi aspek sosial, pemerintahan, dan hukum (adat).

Setiap manusia dalam lingkungannya memegang peranan dalam kehidupan dengan status yang dimilikinya. Menurut Ralph Linton, ada dua macam status yaitu:

a. Ascribed status, yaitu status yang diperoleh berdasarkan wewenang.

b. Achieved status, yaitu status yang diperoleh dengan usaha sendiri.

Adapun peranan mengandung pengertian suatu perilaku yang diharapkan oleh orang lain yang menduduki status tertentu. Pendapat ini sejalan dengan pernyataan William F. Kendel yang mengatakan bahwa apabila seseorang mempunyai kedudukan maka ia akan diberi sejumlah harapan untuk dapat melaksanakan sesuai kedudukan yang disandangnya. Peranan juga meliputi aspek-aspek kehidupan yang 
luas dari individu tersebut. Peranan bukan hanya dikaitkan dengan posisi dalam suatu kedudukan/pekerjaan namun mecakup sikap, perilaku, dan tanggung jawab pada masyarakat.

Selanjutnya yang dimaksud pemimpin informal ialah orang yang berpengaruh dan diakui sebagai pemimpin oleh suatu kelompok atau masyarakat pedesaan dan tidak memegang jabatan resmi dalam pemerintahan desa. Menurut Koentjaraningrat (1977:41) yang dimaksud pimpinan informal adalah pimpinan yang tidak diangkat langsung oleh pemerintah tetapi mempunyai pengaruh yang luas dalam masyarakat bahkan lebih besar pengaruhnya dari pemimpin formal. Pemimpin adat adalah termasuk pemimpin informal tradisional yang memiliki pengaruh dan peranan besar dalam masyarakat pedesaan. Apabila berbicara tentang peranan pe-mimpin adat, maka secara tidak langsung membicarakan peranannya dalam masyarakat yaitu bagaimana pemimpin adat sebagai pemimpin informal tradisional membawakan peranannya dalam proses perubahan, yaitu sebagai mediator atau cultural agent yang bertugas untuk melaksanakan program pembangunan sekaligus mempertahankan adat istiadat masyarakat yang dipimpinnya.

Sesuai dengan permasalahan yang diungkapkan di atas maka penelitian ini bertujuan:

a. Mengetahui bagaimana peranan pemimpin informal dalam kehidupan masyarakat Guradog, yang meliputi peranan pada aspek sosial, aspek pemerintahan, dan aspek hukum (adat).

b. Pada akhirnya penelitian ini diharapkan berguna memberi masukan bagi pembuat kebijakan dalam kaitannya dengan pembinaan lembaga adat khususnya pemimpin informal (adat) yang memiliki peranan penting dalam kehidupan masyarakat.

Adapun ruang lingkup penelitian ini adalah mengenai peranan pemimpin adat pada kehidupan masyarakat Guradog, meliputi peranan pada aspek sosial , aspek pemerintahan, dan hukum adat. Pada aspek sosial, peranan bisa dilihat dalam memimpin musyawarah, memimpin upacara adat, tempat bertanya dan meminta nasihat, serta panutan masyarakat dalam melaksanakan tata cara kehidupan sehari-hari. Pada aspek pemerintahan bisa dilihat pada tugas pemimpin adat dalam membantu perangkat desa menyampaikan program pembangunan dari pemerintah pada masyarakat. Sedangkan pada aspek hukum bisa dilihat dari tugas pemimpin adat melaksanakan hukum adat dalam kehidupan sehari-hari yang berdasarkan hukum Islam.

Sesuai dengan permasalahan penelitian, maka metode yang digunakan adalah deskriptif karena masalah yang diteliti sedang berlaku dalam kehidupan masyarakat. Kegiatan yang dilakukan adalah mencari dan mengumpulkan data mengenai peranan pemimpin adat dalam kehidupan masyarakat. Dengan metode kualitatif, data yang diambil diharapkan dapat menggambarkan mengenai peranan pemimpin adat pada masyarakat Guradog. Untuk pengumpulan data digunakan teknik observasi dan wawancara mendalam pada sejumlah informan. Informan yang dipilih adalah pemimpin informal masyarakat, seperti olot (sesepuh adat), pembantu olot, ulama, sesepuh, dan sebagian masyarakat serta pemimpin formal yaitu perangkat desa.

Lokasi penelitian dilaksanakan di Desa Guradog, Kecamatan Curug Bitung, Kabupaten Lebak Propinsi Banten. Dipilihnya lokasi penelitian ini, 
berdasarkan pertimbangan bahwa pemimpin tertinggi masyarakat Guradog dipegang oleh seorang pemimpin adat (olot) dan pembantu olot ( sekretaris adat, baris kolot, dan pangiwa). Dalam melaksanakan tata cara kehidupan seharihari, masyarakat berpegang teguh pada penuturan pemimpin informal (olot dan pembantu olot), baik mengeni hal-hal yang dilarang (tabu) maupun kewajiban yang harus ditaati masyarakat. Dapat dikatakan peranan sesepuh adat sangat strategis dalam membina kerukunan hidup masyarakat Guradog.

\section{B. Hasil dan Bahasan}

Desa Guradog merupakan salah satu desa yang berada di Kecamatan Curug Bitung Kabupaten Lebak. Lokasi desa ini sekitar 17 kilometer dari ibu kota kecamatan dan 36 kilometer dari ibu kota kabupaten. Desa Guradog berada pada ketinggian 100-400 meter di atas permukaan air laut yang memiliki bentang wilayah berbukit, sebagian besar tanah berwarna merah atau kuning. Suhu rata-rata antara 32 sampai 40 derajat Celsius. Jumlah curah hujan dalam tiap tahun berlangsung selama 9 bulan dengan curah hujan $1.500 \mathrm{~mm} / \mathrm{tahun}$. Luas keseluruhan Desa Guradog sekitar 1.020,39 hektar terdiri dari tanah sawah, tanah kering, tanah perkebunan, dan pemukiman.

Komposisi penggunaan lahan
tersebut menggambarkan mata pencaharian penduduk Desa Guradog yakni sebagai petani sawah atau kebun serta pekerjaan yang berkaitan dengan hutan seperti penyadap, tukang kayu, atau pembuat arang. Sekalipun dalam jumlah relatif sedikit, terdapat pula penduduk dengan mata pencaharian di luar bidang pertanian di antaranya sebagai buruh dan pegawai negeri sipil (PNS). Berdasarkan kependudukan, Desa Guradog berpenduduk sebanyak 3.716 orang dengan komposisi jenis kelamin 1.877 orang laki-laki dan 1.839 perempuan. Jumlah tersebut terdiri atas 919 kepala keluarga (KK). Penduduk Desa Guradog kebanyakan tidak dapat memasuki dunia kerja formal mengingat dasar pendidikan yang dimiliki oleh mereka sangat rendah. Rendahnya keikutsertaan anak didik di bangku sekolah disebabkan oleh terbatasnya fasilitas persekolahan di Desa Guradog. Keterbatasan fasilitas sekolah ini menyebabkan tingginya biaya penyelenggaraan pendidikan untuk ukuran ratarata masyarakat Desa Guradog, terutama untuk biaya transportasi dari rumah ke sekolah yang lokasinya berada di luar Desa Guradog. Faktor rendahnya kesadaran akan pentingnya pendidikan termasuk hal yang menyebabkan rendahnya minat peserta didik untuk bersekolah. Pola pikir para orang tua yang lebih mementingkan untuk mengelola alam menjadi penyebab lain rendahnya kesadaran untuk bersekolah. Alam Desa Guradog yang subur, memang sangat memerlukan tenaga yang banyak untuk mengolah menjadi bumi yang produktif. Dengan mengolah alam menjadi lebih produktif menyebabkan mudah dalam menghasilkan uang, sebagai contoh terdapat beberapa potensi alam yang mampu mendatangkan uang seperti: getah karet, batu gunung, bambu, kayu, dan lain sebagainya. Bahan ini sangat mudah diperoleh dan jika dijual dapat dengan cepat menghasilkan uang.

Penduduk Desa Guradog seluruhnya beragama Islam. Oleh sebab itu, tempat-tempat beribadat yang terdapat di Desa Guradog hanya berupa mesjid dan langgar. Jumlah mesjid yang terdapat di Desa Guradog sebanyak 4 mesjid dan 3 langgar atau mushola. Adapun pola pemukiman masyarakat Desa Guradog termasuk tipe mengelompok yakni menempati 
sepanjang jalan besar dan gang dengan arah menghadap ke jalan. Biasanya rumah baris pertama yang menghadap jalan akan diikuti oleh rumah-rumah lain di belakangnya. Arah rumah yang demikian lebih mementingkan jalinan hubungan sosial dengan tetangga agar terus terjalin. Di Desa Guradog mengalir tiga buah sungai, yakni Sungai Citundun, Sungai Ciapus, dan Sungai Citembong. Sungai-sungai tersebut dimanfaatkan untuk menunjang kehidupan masyarakat, di antaranya untuk mencuci, mandi, dan kakus. Kelompok rumah lainnya menempati lahan yang berada jauh dari jalan raya atau sungai yakni di sekitar sawah atau kebun. Pemilik rumah yang mendirikan rumah di lokasi ini karena mereka tidak memiliki lahan di tempat lain atau sengaja mendirikan rumah di tempat tersebut dengan maksud agar dekat dengan sawah atau ladang miliknya.

\section{Desa Guradog Sebagai Desa Adat}

Desa Guradog merupakan desa yang dikategorikan sebagai desa adat. Komunitas warga Desa Guradog disebut sebagai komunitas adat kasepuhan atau kaolotan. Sebutan kasepuhan/kaolotan menunjuk suatu sistem kepemimpinan dari suatu komunitas atau kelompok sosial, di mana semua aktivitas anggotanya berazaskan adat para orang tua (sepuh atau kolot). Terlihat dalam tata cara kehidupan mereka yang masih kukuh menjalankan tatali paranti karuhun (K.Adimihardja pada Rosyadi, 2005: 28). Kehidupan masyarakat Desa Guradog termasuk kehidupan yang khas. Kepemimpinan masyarakatnya diatur oleh dua tipe kepemimpinan yakni pemimpin formal dan pemimpin informal. Kedua tipe kepemimpinan tersebut berjalan selaras dalam mengatur gerak dan langkah masyarakat Desa Guradog.
Pemimpin formal mengatur gerak masyarakat yang terkait dengan program pembangunan yang diselenggarakan oleh pemerintah. Dengan demikian, pemimpin formal akan menjembatani pelaksanaan program pemerintah dengan masyarakat. Struktur organisasi kemasyarakatan formal diisi oleh camat, kepala desa, ketua RW, dan ketua RT. Pemimpin formal ini ditunjuk oleh masyarakat melalui pemilihan yang demokratis dan disetujui atau diangkat berdasarkan surat keputusan dari pemerintah. Dasar hukum yang digunakan oleh pemimpin formal dalam mengelola masyarakat adalah undang-undang dan ketentuan pemerintah lainnya. Sanksi bagi pelanggar undang-undang dan ketentuan lainnya adalah yuridis formal yang berupa hukum pidana dan perdata.

Di Desa Guradog, selain terdapat pemimpin formal, juga terdapat pemimpin informal yang disebut olot. Dasar hukum yang digunakan oleh pemimpin informal ini adalah adat yang sudah berlaku turun-temurun dan dipatuhi oleh warganya. Pemimpin informal merupakan pemimpin adat masyarakat Desa Guradog yang menjadi bagian dari Kesatuan Adat Banten Kidul. Dalam melaksanakan perannya, kedua pemimpin ini saling bekerjasama satu dengan lainnya. Tujuan utama mereka adalah membawa kehidupan masyarakat agar damai, rukun, dan sejahtera. Kerja sama yang baik dan padu ditunjukkan oleh falsafah tuli sapamilu, dua sakarupa, nu hiji eta keneh (tiga bersama-sama, yang dua masih serupa, yang menjadi satu masih yang itu juga). Maksud falsafah tilu sapamilu adalah tiga komponen pemerintahan, agama, dan tradisi harus berjalan dengan selaras dan harmonis. Dua sakarupa berarti antara tradisi dan agama jangan dipisahkan dan dipertentangkan. $\mathrm{Nu}$ hiji eta kenah maksudnya semua komponen tersebut 
harus menuruti dan sesuai dengan aturan negara yaitu Negara Kesatuan Republik Indonesia.

Kedua model kepemimpinan tersebut di atas memiliki tugas dan kewenangan masing-masing. Pemimpin formal melaksanakan semua urusan yang terkait dengan administrasi kenegaraan, seperti pembuatan KTP, kartu keluarga, surat pengantar, atau berbagai surat keterangan. Pemimpin informal mengelola masyarakat dari sisi spiritual dan adat yang tidak mungkin dilakukan oleh pemimpin formal seperti pelaksanaan upacara adat, konsultasi tentang nasib, penentuan hari baik, perjodohan, dan lain sebagainya. Masyarakat menggunakan kewenangan kedua pemimpin tersebut secara tepat, sehingga tidak pernah terjadi benturan kewenangan. Bahkan jika melihat kenyataan, pemimpin informal memiliki tugas dan kepercayaan yang lebih besar dibandingkan pemimpin formal mengingat hampir seluruh tatanan kehidupan diatur dengan adat dan masyarakat selalu konsultasi dengan pemimpin informal. Bahkan adakalanya untuk memperlancar komunikasi dalam pelaksanakan program pembangunan pemerintah, pemimpin formal sering meminta bantuan pemimpin informal.

\section{Olot: Pemimpin Informal (Adat) di Desa Guradog}

Dengan tugas dan fungsi pemimpin informal yang begitu banyak, menunjukkan bahwa peran dan kedudukan pemimpin informal sangat penting. Ketua adat yang sekaligus merupakan pemimpin mereka disebut olot yang menduduki tempat tertinggi dalam struktur masyarakat Desa Guradog. Jabatan olot diperoleh melalui garis keturunan yang jatuh pada turunan laki-laki yakni anak laki-laki atau adik laki-laki. Hal ini sangat tergantung pada kesiapan dan kelayakan turunan yang akan menggantikan jabatan olot. Olot atau ketua adat ini dibantu juga oleh beberapa pembantu yakni sekrtetaris adat, 30 baris kolot, dan pangiwa. Mereka ini sebagai penasihat dan pembantu olot dalam menjalankan kehidupan yang berkaitan dengan adat atau tradisi di Desa Guradog.

Seorang ketua adat atau olot diharapkan mampu berpikir bijak, menjadi panutan, dan melindungi warganya. Hal yang lebih utama adalah seorang olot harus mampu menjaga agar tradisi yang telah turun-temurun dilakukan tetap lestari, dapat berjalan selaras dengan agama yang dianut masyarakat dan selaras pula dengan peraturan pemerintah. Pada awalnya, peran olot hanya sebagai pembimbing masyarakat pada hal-hal yang berkaitan dengan adat , namun kini tugas olot berkembang hampir seluruh aspek kehidupan masyarakat di berbagai aktivitas sosial dan sebagai media pemerintah dalam penyampaian program pembangunan.

Fungsi olot sebagai pemimpin informal sangat berperan menjaga nilainilai luhur budaya peninggalan para karuhun. Salah satu penerapan normanorma tersebut dengan memberlakukan pantangan atau tabu. Setiap anggota masyarakat yang mempercayainya harus patuh pada pantangan tersebut. Selain itu persatuan dan kerukunan oleh olot diterapkan juga dalam sistem pemilihan lurah. Bukti menunjukkan sekalipun calonnya hanya satu dan berasal dari keluarga olot, suara mutlak pemilih selalu terpenuhi. Dari bukti ini menunjukkan bahwa olot tidak gegabah dalam menentukan calon lurah, serta suara penuh yang ditunjukkan oleh pemilih menunjukkan rasa setuju atas figur pemimpin yang dipilihnya. Namun demikian olot tidak dapat berbuat sewenang-wenang, menentukan semuanya seorang diri, dia didampingi oleh 
penasihat lain yang tugasnya memberi saran untuk segala permasalahan. Kelompok tersebut disebut baris kolot. Dengan demikian, baris kolot akan selalu mengadakan pengawasan terhadap segala keputusan yang diambil olot, hingga keputusan-keputusan yang diambil oleh olot akan selalu berpihak kepada kepentingan masyarakat.

Olot adalah sebutan ketua adat di Guradog yang merupakan lapisan sosial tertinggi berdasarkan keturunan. Saat ini yang menjadi ketua adat di Guradog adalah keturunan keempat dari olot sebelumnya. Olot berfungsi sebagai pemimpin adat yang bertanggung jawab penuh atas kelangsungan adat istiadat yang ada di Guradog. Selain itu juga sebagai mediator pemerintah dalam menyampaikan program-program pembangunan seperti pemilihan kepala desa (kades), KB, perbaikan jalan, kesehatan, pendidikan dan lain sebagainya. Boleh dikata ketua adat (olot) ini memiliki peran ganda dalam masyarakat. Dalam menjalankan tu-gasnya, olot juga dibantu oleh sekretaris adat. Sekretaris adat ini juga merupakan keturunan adat yang berasal dari Kampung Alung. Dia dipilih sebagai sekretaris adat karena memiliki garis keturunan adat dari sekretaris adat sebelumnya. Sekretaris adat berfungsi sebagai pembantu olot dalam memimpin musyawarah arau rapat adat, kegiatan upacara adat, dan menyelesaikan masalah adat. Selain sekretaris adat, olot juga dibantu oleh pangiwa yakni orang yang membantu dalam menyebarkan undangan atau pengumuman yang berkaitan dengan adat. Orang yang menjadi pangiwa adalah orang yang memiliki garis keturunan adat. Olot, sekretaris adat, dan pangiwa inilah orang yang sangat dihormati dan disegani oleh masyarakat Guradog. Jabatan ini didapat secara turun-temurun dari orang tua sebelumnya, kemudian dipilih oleh masyarakat. Boleh dikata ketiga tokoh ini yang menjadi panutan dan tempat bertanya masyarakat Guradog dalam kehidupan sehari-hari. Terlebih olot, apa yang dikatakan atau dilarang olehnya dipatuhi oleh masyarakat.

Dilihat dari sejarahnya, kepala desa di Desa Guradog semuanya masih keturunan dari keluarga olot. Ini mengisyaratkan bahwa olot memiliki pengaruh dan peranan yang penting pada masyarakat Guradog. Dalam pemilihan kepala desa pun juga dipengaruhi oleh keputusan olot. Di Desa Guradog selain lembaga formal seperti kepala desa, RT, RW, juga terdapat lembaga adat yang menjalankan fungsi-fungsi adat istiadat setempat. Lembaga adat adalah struktur masyarakat yang didasarkan pada kedudukan adat serta menjalankan fungsi-fungsi adat-istiadat setempat. Struktur lembaga adat terdiri atas ketua adat dengan istilah sapaan "olot", sekretaris adat, baris kolot, dan pangiwa. Ketua adat (olot) memimpin hampir semua aktivitas pelaksanaan adat-istiadat penduduk setempat. Ketua adat juga menentukan dan memutuskan semua perkara yang bertalian dengan aturanaturan adat yang harus senantiasa ditaati oleh semua warga Guradog. Adapun sekretaris adat bersama olot bertugas untuk memimpin rapat atau musyawarah warga yang dilakukan sebulan sekali.

Ketua adat di Desa Guradog disebut dengan istilah "olot", menempati posisi sangat penting dalam struktur masyarakat setempat. Olot sekarang adalah $\mathrm{H}$. Ono yang merupakan keturunan ketiga dari olot sebelumnya. Olot selain memimpin hampir semua aktivitas pelaksanaan adat-istiadat masyarakat juga membantu dalam hal urusan pemerintahan. Semua warga Guradog harus menaati ketentuan yang disampaikan oleh olot. Oleh sebab itu, 
kedudukan olot sangat dihormati di lingkungan warganya.

Posisi selanjutnya adalah para pembantu olot yang disebut dengan sekretaris adat, pangiwa, dan baris kolot. Baris kolot terdiri atas orang-orang pilihan yag berpengaruh di Desa Guradog. Para pembantu olot ini masingmasing memiliki tugas khusus dan menjadi tangan kanan olot dalam setiap penyelenggaraan upacara adat atau hal lain yang berkaitan dengan pemerintahan. Sekretaris adat membantu olot dalam memimpin rapat atau musyawarah adat dan menyelesaikan berbagai masalah adat. Pangiwa adalah orang yang membantu menyampaikan undangan atau pengumuman hasil rapat adat. Sedangkan baris kolot yang terdiri dari 30 orang keturunan adat adalah orang yang membantu pekerjaan sekretaris adat dan olot dalam membuat keputusan. Secara skematis, struktur sosial komunitas adat masyarakat Guradog dapat digambarkan sebagai berikut:

$$
\begin{gathered}
\text { Ketua Adat (Olot) } \\
\downarrow \\
\text { Sekretaris adat } \\
\downarrow \\
\text { Baris Kolot } \\
\downarrow \\
\text { Pangiwa }
\end{gathered}
$$

Kedudukan ketua adat (olot) diwariskan secara turun-temurun.

\section{Pemimpin Informal di Desa Guradog}

Peminpin informal dalam hal ini pemimpin adat di pedesaan memiliki peranan yang cukup besar dalam kehidupan masyarakat, baik sebagai mediator pemerintah maupun sebagai pemimpin adat. Demikian pula di Desa Guradog yang merupakan kampung adat di Kabupaten Lebak memiliki pemimpin adat yang disebut ketua adat dengan sapaan olot, yang dihormati dan menjadi panutan masyarakatnya. Dalam melaksa- nakan tata cara kehidupan sehari-hari, masyarakat Guradog berpegang teguh pada penuturan olot yang dianggap sebagai pemimpin tertinggi. Aturan dan tutur kata pemimpin adat sangat ditaati oleh masyarakatnya. Oleh sebab itu, sesepuh adat merupakan tempat bertanya, meminta nasihat, dan petunjuk. Dalam kehidupan sosial, sesepuh adat berperan sebagai pemimpin adat dalam mempertahankan nilai-nilai yang dianut oleh masyarakatnya.

Selain itu, ketua adat di Guradog memiliki peranan penting dalam aspek pemerintahan yakni sebagai mediator bagi pemerintah dalam menyampaikan program pembangunan. Ketua adat ikut berperan dalam membantu perangkat desa dalam menyebarluaskan informasi pembangunan pada masyarakat. Demikian pula dalam aspek hukum, ketua adat melaksanakan hukum adat dalam kehidupan sehari-hari yang berlandaskan agama Islam.

Secara umum sebagai pemimpin adat, ketua adat selalu menjadi tokoh panutan yang berperan dalam mengatur dan mempertahankan nilai-nilai adat yang dianut masyarakat. Berikut ini diuraikan tentang peranan ketua adat yang disebut dengan olot dalam kehidupan masyarakat Guradog, meliputi peranan pada aspek sosial, aspek pemerintahan, dan aspek hukum. Namun, sebelum itu akan dibahas mengenai sosok ketua adat atau olot Guradog dan para pembantu adat.

Olot, H. Ono, adalah anak ke-4 dari 10 bersaudara dan merupakan keturunan ke-3 dari olot sebelumya, yakni $\mathrm{H}$. Kadung (orang tua) dan $\mathrm{H}$. Sarmin (kakek). H. Kadung memiliki 10 orang anak, dan hampir semua anak telah melaksanakan ibadah haji. Anak-anak H. Kadung memiliki jabatan atau kedudukan penting baik di pemerintahan maupun masyarakat yakni sebagai kepala desa 
dan tokoh agama yang memimpin setiap acara keagamaan di Desa Guradog. Saudara-saudaranya yang lain pun dianggap keluarga mampu dan terpandang, karena memiliki usaha perkebunan karet yang cukup sukses.

Dalam menjalankan tugas, ketua adat (olot) dibantu oleh sesepuh adat yang lain yakni sekretaris adat, baris kolot, dan pangiwa. Saat ini yang menjabat sebagai sekretaris adat adalah Bapak Harun. Sekretaris adat memiliki peran yang sangat penting, yakni sebagai pelaksana semua kegiatan adat, musyawarah adat, dan menyelesaikan semua masalah. Dapat dikatakan tugas yang diemban sekretaris adat cukup berat dan dia juga sering mewakili olot pada acara-acara tertentu jika olot tidak bisa hadir. Pengetahuan adat yang dimiliki Bapak Harun cukup luas, oleh karena itu banyak warga yang datang untuk minta petunjuk atau restu. Misalnya jika ada warga yang mau menikahkan anaknya, maka mereka melakukan upacara maros yakni mohon doa restu dan "minta hari baik" pada Bapak Harun. Syarat yang harus dipenuhi adalah membawa seperangkat sirih yang dibungkus dengan daun pisang lengkap dengan rokok satu bungkus dan uang sekedarnya minimal 10 ribu rupiah. Pada acara maros ini, orang yang datang diberi doa ijab kabul oleh Bapak Harun, kemudian mereka disuruh pulang untuk menunggu penentuan "hari baik". Bersama H. Itok (pemuka agama) dan ke-30 baris kolot, Bapak Harun menentukan hari baik dan hal-hal lainnya yang berkaitan dengan kelancaran upacara. Seminggu kemudian mereka sudah mendapatkan jawaban tentang hari baik tersebut.

Sekretaris adat dalam menjalankan tugasnya dibantu oleh 30 baris kolot, yakni orang yang masih memiliki garis keturunan adat.. Ke-30 baris kolot tersebut membantu sekretaris adat dalam membuat semua keputusan yang menyangkut masalah adat. Hasil keputusan tersebut kemudian dilaporkan pada olot. Jika ada satu permasalahan maka olot, sekretaris adat, dan baris kolot bermusyawarah untuk membuat satu keputusan. Ke-30 baris kolot ini juga ikut mengerjakan sawah adat yang hasilnya untuk kepentingan warga seperti untuk biaya dalam pelaksanaan upacara adat yang membutuhkan dana dan beras. Secara bergiliran ke-30 baris kolot tersebut mengerjakan sawah adat mulai dari menanam sampai panen.

Selain dibantu oleh ke-30 baris kolot, sekretaris adat juga dibantu oleh pangiwa yakni orang yang menyampaikan undangan dan pengumuman pada warga. Dalam menyampaikan undangan biasanya secara lisan melalui pengeras suara di mesjid. Saat ini yang menjabat sebagai pangiwa adalah Bapak Madsuni yang masih memiliki garis keturunan adat. Selain sebagai pangiwa, Bapak Madsuni menjabat juga sebagai kepala RW di wilayah Desa Guradog. Sesepuh adat lain adalah pemuka agama yakni Kyai H. Itok beserta para ustadz. Pemuka agama ini memiliki peranan penting dalam kegiatan keagamaan maupun adat. Kyai Itok adalah adik dari olot $\mathrm{H}$. Ono yang sangat disegani oleh masyarakat Guradog. Sebagai Kyai, dia juga sering didatangi warga untuk dimintai pertolongan atau nasihat tentang perkawinan, perjodohan dan lain sebagainya. Seperti halnya keluarga H. Ono, Kyai Itok ini cukup berada. H. Itok dilahirkan 51 tahun yang lalu di Guradog. Tinggal bersama istri dan tiga anaknya yang belum menikah, semuanya masih sekolah. H. Itok sehari-hari aktif mengelola Pondok Pesantren Rodatul Mutaqin dan penyelenggara salafi yakni sekolah SLTP nonformal serta aktif di badan zakat amil (BAZ). Selain itu juga sebagai pengusaha karet dan petani 
sawah yang memiliki lahan kurang lebih $20 \mathrm{Ha}$.

Demikianlah pemimpin adat yang ada di Desa Guradog, ternyata mempunyai peranan penting dalam menjaga tradisi atau adat istiadat agar tidak tergerus oleh jaman. Meskipun sistem kepemimpinan pada masyarakat Guradog terbagi dalam pemimpin formal dan informal, akan tetapi peranan pemimpin informal dalam hal ini ketua adat (olot) dan semua pembantunya (sekretaris adat, baris kolot, pangiwa) memiliki peranan menonjol bila dibandingkan dengan pemimpin formal. Terbukti semua keputusan olot sangat dipatuhi oleh warga, oleh sebab itu setiap adanya program pemerintah selalu melibatkan pemimpin informal yang digunakan sebagai media pada masyarakat untuk menyampaikan program pembangunan. Bahkan setiap keputusan kepala desa dalam setiap musyawarah atau rapat yang selalu dihadiri para sesepuh adat selalu dipengaruhi oleh persetujuan olot.

Dari uraian di atas, tampak bahwa peminpin informal dalam hal ini pepimpin adat memiliki tugas penting dalam mengatur semua aktivitas warga Desa Guradog, yaitu meliputi aspek sosial, hukum, dan pemerintahan. Tidak hanya sebagai pemimpin upacara adat saja, melainkan sebagai culture agent atau perantara dan pengendali sosial bagi masyarakat Guradog. Berikut ini akan dikemukakan peranan pemimpin informal dalam hal ini olot dan para sesepuh adat lainnya meliputi aspek sosial, pemerintahan, dan hukum adat.

\section{Peranan Pemimpin Informal dalam \\ Aspek Sosial}

Dalam kaitannya dengan tata cara kehidupan sehari-hari, ketua adat mempunyai peranan yang cukup penting, yaitu memberikan petuah dan menjelaskan tentang riwayat Desa
Guradog. Pemberian petuah dilakukan pada saat:

a. Pengajian warga yang diselenggarakan setiap malam Jum'at. Pada saat itu olot memberi petuah atau nasihat mengenai adat atau tata cara yang dilakukan oleh leluhur pada warga terutama kaum muda yang dinilai masih awam dan kurang mendalami aturan adat istiadat yang berlaku.

b. Musyawarah atau adanya pertemuan, karena saat itu seluruh warga hadir. Misalnya dalam pelaksanaan upacara adat seren taun dan ngarengkong. Selain itu, sesepuh adat sering mengaitkan halhal yang sedang dimusyawarahkan dengan aturan adat di Guradog

Pada aspek sosial, ketua adat (olot) dan para pembantunya (sekretaris adat, baris kolot, pangiwa) pun memegang perasaan sangat penting dan menonjol. Hal ini terlihat dari tugas-tugas yang diembannya, yaitu:

a. Sesepuh adat bertugas mencarikan dan menentukan "hari baik" warga yang akan melangsungkan pernikahan. Orang tua yang akan menikahkan anaknya, akan datang padanya untuk mananyakan tentang hari baik pernikahan anaknya. Menurut Bapak Harun, penentuan hari baik ditentukan dengan cara menghitung dari hari lahir calon pengantin. Demikian pula bagi orang yang akan mengkhitankan anaknya, terlebih dahulu dicarikan hari baik .

b. Sekretaris adat bertugas melayani tamu yang datang untuk berziarah ke makam keramat H. Sarmin. Makam tersebut sangat ramai dikunjungi peziarah, terutama pada saat upacara seren taun dan ngarengkong. Selain berziarah, ada juga pengunjung yang menginap di makam tersebut untuk 
meminta berkah demi kemajuan usaha, kenaikan pangkat, bahkan untuk keberhasilan sekolah. Sebagai pemimpin adat, olot dan sekretaris adat dianggap sebagai tokoh masyarakat yang sangat disegani dan dihormati. Hal ini tampak dalam persiapan upacara perkawinan dan upacara adat lainnya, mereka selalu diharapakan hadir untuk memberi doa restu. Kehadirannya sangat diharapkan warga, karena dianggap memberikan berkah dan doa restu.

c. Olot dan para pembantunya juga berperan sebagai pemimpin dalam kegiatan rapat atau musyawarah warga. Di Desa Guradog, sebulan sekali diadakan rapat yang membahas mengenai keamanan, kebersihan, dan kegiatan warga lainya. Dalam pertemuan tersebut, olot dan sesepuh adat lainnya bertindak sebagai sesepuh yang memberi petuah atau nasihat serta memimpin rapat agar berjalan lancar. Keputusan akhir memang pada musyawarah juga, namun arahan dan petunjuk dari olot sebagai sesepuh adat sangat diperlukan.

d. Olot juga bertugas dalam menjaga kebersihan, keamanan, dan pemeliharaan makam leluhur. Meskipun sudah dijaga oleh seorang kuncen yang bertugas memelihara dan merawat makam leluhur, namun secara khusus olot $i$ kut bertanggung jawab mengenai kebersihan dan keamanan. Setiap hari Jum'at bersama warga melaksanakan kegiatan Jumsih (Jum'at bersih) dengan membersihkan makam dan lingkungan sekitar, sehingga Desa Guradog kelihatan tertata rapih, bersih, dan rindang.

Untuk menjaga keharmonisan ini manusia berusaha untuk menjembatani dengan melakukan upacara ritual agar mendapatkan keselamatan. Disinilah olot dan para sesepuh adat berperan sebagai orang yang dianggap mampu sebagai mediator yang menghubungkan antara dunia sana (alam gaib) dengan dunia sini. Olot dan para sesepuh adat lainnya senantiasa memimpin semua ritual upacara adat. Bagaimanapun juga, pemimpin adat merupakan mediator antara masyarakat Guradog dengan para karuhunnya. Adapun pelaksanaan upacara itu sendiri merupakan sarana transformasi nilai-nilai dan tradisi dari satu generasi ke generasi berikutnya. Hampir setiap upacara melibatkan peserta mulai dari kalangan anak-anak, remaja, orang tua, laki-laki, dan perempuan. Salah satu contoh peranan yang dilakukan oleh olot sebagai sesepuh adat dan para pinisepuh lainnya adalah pada pelaksanaan upacara tradisional atau upacara adat. Pada acara tersebut terlihat jelas bagaimana fungsi dan tugas yang diembannya dalam memimpin pelaksanaan upacara tersebut dari awal sampai akhir.

\section{Peranan Pemimpin Informal dalam \\ Aspek Pemerintahan}

Peranan sesepuh adat dalam aspek pemerintahan dapat dilihat dari tugastugas yang diembannya, antara lain:

a. Sesepuh adat dalam hal ini olot, ikut serta dalam menyebarluaskan informasi pembangunan pada masyarakat Guradog. Progamprogam pembangunan yang dijalankan pemerintah, seperti keluarga berencana (KB), ling-kungan hidup, kesehatan ibu dan anak, kebersihan dan ketertiban, dan keindahan (K3), dan pendidikan generasi muda, akan berhasil dengan melibatkan olot sebagai pemimpin informal. Melalui peran sertanya, informasi pembangunan 
akan lebih efektif sampai pada masyarakat karena segala tutur katanya sebagai sesepuh masyarakat akan dijadikan panutan dan pedoman.

b. Sesuai dengan Undang-Undang Nomor 5 Tahun 1979, pemerintahan desa yang terdiri atas kepala desa dan Lembaga Musyawarah Desa (LMD) dalam tugasnya dibantu oleh sekertaris desa dan kepala dusun. Ketika melaksanakan tugasnya seharihari, kepala desa selain dibantu oleh perangkat desa lainnya, juga dibantu oleh olot dan sesepuh adat yang lain. Mereka dilibatkan dalam proses pengambilan keputusan dan penyebarluasan informasi pada masyarakat. Kenyataannya, hal ini sangat efektif karena suara atau anjuran pemimpin adat lebih didengar dan dipatuhi oleh masyarakat.

Dalam aspek pemerintahan dapat dilihat dari tugas-tugas yang diembannya, antara lain: sesepuh adat dalam hal ini olot dan sekretaris adat ikut serta dalam menyebarluaskan informasi pembangunan pada masyarakat Guradog. Progamprogam pembangunan yang dijalankan pemerintah, seperti keluarga berencana (KB), lingkungan hidup, kesehatan ibu dan anak, kebersihan dan ketertiban, dan keindahan (K3), dan pendidikan generasi muda, akan berhasil dengan melibatkan ketua adat. Melalui peran sertanya, informasi pembangunan akan lebih efektif sampai pada masyarakat karena segala tutur katanya akan dijadikan panutan dan pedoman. Olot dan sekretaris adat selalu diikutsertakan dalam setiap kegiatan dari pemerintah misalnya pada tahun 1995 ketika progam kesehatan diadakan, dijadikan sebagai motivator (memberikan dorongan) dan katalisator (penggerak) pada warga agar bersedia ikut mensukseskan terlaksananya progam tersebut (Jumsih, GDN, dll).

\section{Peranan Pemimpin Informal dalam Aspek Hukum}

Dalam aspek hukum, di Desa Guradog tidak terdapat hukum adat tertulis secara formal, namun dalam kehidupan sehari-hari masyarakat masih berpegang pada hukum adat yang berupa norma dan nilai yang berlaku. Aturanaturan seperti hukum perdata dan hukum pidana, tetap berpedoman pada hukum pemerintah. Kaitannya dengan hukum perdata dan pidana yang dikeluarkan oleh pemerintah, sesepuh adat tutrut membantu pelaksanaan hukum pemerintah tersebut dengan tidak melepaskan norma dan kaidah hukum yang ada dalam ajaran agama Islam.

Pelaksanaan tugas sesepuh adat dalam menerapkan hukum tersebut terwujud aturan adat sebagai berikut:

\section{a. Penyelesaian masalah pelanggaran hukum di lingkungan masyarakat Guradog.}

Apabila salah seorang anggota masyarakatnya melanggar adat atau tidak patuh pada adat, maka secara adat akan dimusyawarahkan pada tingkat warga yang dipimpin oleh sekretaris adat bersama ke-30 baris kolot. Dalam musyawarah tersebut dicari cara penyelesaian masalah yang dinilai terbaik, biasanya secara damai atau kekeluargaan. Walaupun diselesaikan secara damai atau kekeluargaan tidak berarti sesepuh adat tidak memberikan sanksi, dia tetap melakukan hukum adat dan memberikan sanksi yang berlaku. Selanjutnya diberikan nasihat agar kasus serupa tidak terulang lagi, misalnya pada kasus pencurian pelakunya akan ditindak dan dinasihati. Sanksi lebih keras dapat dilakukan, yaitu berupa pengusiran dari Desa Guradog selama waktu tertentu dan 
dapat kembali lagi jika dinilai sudah bertabiat baik dan bertobat. Jika cara tersebut dapat menyelesaikan masalah, maka kasus itu diserahkan kepada Kades dan pihak kepolisian melalui RT dan RW guna diselesaikan secara hukum pemerintahan yang berlaku.

\section{b. Penyelesaian masalah yang berkaitan dengan hukum waris.}

Sesepuh adat menggunakan hukum atau aturan yang ditetapkan oleh ajaran agama Islam. Namun demikian, untuk pembagian harta waris mereka tidak sepenuhnya mengadopsi aturan agama Islam. Mereka memiliki adat istiadat sendiri yang berlangsung turun-temurun. Semua tergantung keputusan orang tua dan tidak ada aturan tertentu, tapi biasanya dibagi rata. Aturan adat menentukan anak laki-laki dan perempuan memiliki hak sama atas warisan orang tuanya yakni. antara lakilaki dan perempuan sama besarnya. Konsep yang mendasari pembagian waris ini adalah pandangan yang menilai lakilaki maupun perempuan adalah sama anaknya dan darah dagingnya. Bila sudah usia lanjut, orang tua cenderung ikut atau bergantung pada anak perempuan ketimbang anak laki-laki. Harta warisan yang sering ditinggalkan oleh warga Guradog yang sudah meninggal biasanya berupa tanah, ternak, sawah, kebun, uang dan emas. Tanah dan rumah diwariskan, karena kedua benda tersebut merupakan kekayaan individual, sehingga kepemilikannya diatur berdasarkan keturunan yang meninggal. Di Guradog jarang sekali warganya memperjual-belikan tanah. Sedapat mungkin mereka tidak menjual tanah pada orang lain, kalaupun terpaksa dijual, akan dijual kepada saudaranya. Tanah, rumah atau kebun adalah barang penting yang akan diwariskan pada anak cucunya. Itu pula sebabnya warga Guradog satu sama lain masih terikat dalam hubungan kerabat.

Demikianlah peranan pemimpin informal pada masyarakat Guradog. Tampaknya peranan ini tidak kalah penting bila dibandingkan dengan pemimpin formal, minimal mereka bersama-sama mengakomodasi semua kepentingan masyarakat Guradog baik itu untuk kepentingan adat maupun pembangunan. Jadi sistem kepemimpinan pada masyarakat Guradog terbagi menjadi dua yakni kepemimpinan formal (Kades, Sekdes, RW,RT) dan informal (olot, sekretaris adat, 30 baris kolot, pangiwa, ulama/kyai/ustad). Selain itu kepemimpinan di Guradog juga dipengaruhi dengan adanya pertalian saudara (hubungan kerabat) antara pemimpin formal dan informal yang masih satu keturunan dari Engkong $\mathrm{H}$. Sarmin dan H. Kadung yakni orang yang dianggap karuhun warga Guradog.

Dalam kenyataannya, sesepuh adat Desa Guradog mempunyai peranan dan kedudukan sangat penting yakni bukan saja sebagai pemimpin adat yang berperan sebagai pemimpin masyarakat secara adat dan pelindung tradisi warisan leluhur, melainkan juga sebagai tokoh masyarakat yang berperan sebagai mediator pemerintah dalam bidang pendidikan dan sosial.

\section{Penutup}

Ketergantungan masyarakat Guradog terhadap pemimpin adat sebagai orang yang dianggap memiliki kelebihan dari anggota masyarakat yang lainnya, berkaitan erat dengan tugasnya yang berat dan sakral, terutama dalam prinsip dan sikapnya yang selalu memegang teguh tradisi leluhur. Selain itu, dia juga sebagai mediator antara pemerintah dengan masyarakat dalam pelaksanaan progam-progam pembangunan. 
Dalam fungsinya sebagai pelindung adat, sesepuh adat juga berperan sebagai tetua hukum sekaligus sebagai pengambil atau pembuat keputusan dalam menyelesaikan masalahmasalah kehidupan masyarakat Guradog.

Secara umum, peranan pemimpin informal (adat) masyarakat Guradog dapat dikatakan sebagai berikut:

a. Dalam aspek sosial adalah melayani tamu yang berziarah ke makam keramat dan berkunjung ke Desa Guradog, tempat bertanya tentang hari baik, memimpin dalam upacaraupacara adat, mempertahankan nilainilai adat setempat, memimpin rapat warga, dan memimpin warga dalam melaksanakan pembagunan.

b. Dalam aspek pemerintahan adalah sebagai perantara dalam menyampaikan informasi pembangunan, sebagai mediator dalam menyampaikan aspirasi warga, dan membatu kepala desa dalam melaksanakan program pembangunan seperti perbaikan jalan, pemilihan Kades, program KB, pendidikan 9 tahun, siskamling, dan kerja bakti.

c. Dalam aspek hukum adalah penengah dalam menyelesaikan perselisihan antarwarga, aturan adat dalam pola perkampungan, dan pembagian warisan.

\section{Rekomendasi:}

a. Pemimpin informal dalam hal ini pemimpin adat dalam masyarakat pedesaan terbukti memiliki peranan penting, tidak saja sebagai pelestari adat atau tradisi yang masih kuat dilakukan oleh suatu kelompok masyarakat tapi juga bisa digunakan sebagai agen pemerintah dalam penyebarluasan informasi guna kemajuan masyarakat itu sendiri, baik di bidang sosial budaya, pendidikan, dan ekonomi. Mereka dilibatkan dalam pengambilan keputusan di tiap musyawarah dalam pembahasan prog-ram pemerintah.

b. Perlu adanya pembinaan pada tokoh pemimpin adat, agar memiliki pengetahuan dan wawasan luas yang dapat memberikan kontribusi positif bagi kemajuan masyarakat itu sendiri, sepanjang tidak bertentangan dengan aturan adat yang berlaku.

c. Perlu diberi semacam penghargaan pada pemimpin adat baik berupa materi maupun non materi, agar menambah semangat serta motivasi mereka untuk lebih mempertahankan nilai-nilai tradisi dalam masyarakatnya.

\section{DAFTAR PUSTAKA}

Drajat. 1994.

"Kampung Pulo", Akankah tetap lestari?". Pikiran Rakyat, 11 Desember.

Hoebel, E.A. and Weaver T. 1979. Anthropology and the Human Experience. Fifth Edition. New York: Mc Graw-Hill.

Hofsteede. 1977.

Peranan Pemimpin Informal dari Sosiologis. Makalah pada ceramah mengenai "Peranan Sosial Pemimpin Informal dalam Kehidupan Bernegara. Bandung: Fakultas Sospol UNPAD.

Indonesia. Depdikbud. 1990.

Eksistensi Lembaga Adat Kampung Pulo. Bandung: Proyek Penelitian Terhadap Eksistensi Lembaga Adat Pemerintah Propinsi Daerah Tk. I Jawa Barat.

Koentjaraningrat. 1977.

Beberapa Pokok Antropologi Sosial. Jakarta: Dian Rakyat.

Panitia Kamus Lembaga Basa dan Sastra Sunda. 1980.

Kamus Umum Basa Sunda. Bandung: Tarate. 
